\title{
PENGARUH POLA ASUH ORANG TUA DAN PENGGUNAAN GADGET TERHADAP HASIL BELAJAR MATA PELAJARAN IPS SISWA KELAS VII SMP NEGERI 1 SINGOSARI
}

\author{
Fuji Ayu Hidayatul M \\ Universitas Islam Negeri Maulana Malik Ibrahim Malang \\ Fujiayu@gmail.com
}

\begin{abstract}
Abstrak: Berdasarkan teori hasil belajar, Clark menyatakan hasil belajar siswa di sekolah $70 \%$ dipengaruhi oleh kemampuan siswa dan $30 \%$ dipengaruhi oleh lingkungan. Adapun bagian dari lingkungan itu adalah orang tua dan teknologi (gadget). Untuk membuktikan teori tersebut maka tujuan penelitian ini adalah untuk 1. mengetahui seberapa tinggi tingkat pengaruh pola asuh orang tua terhadap hasil belajar mata pelajaran IPS siswa kelas VII di SMPN 1 Singosari, 2. mengetahui seberapa tinggi tingkat pengaruh penggunaan gadget terhadap hasil belajar mata pelajaran IPS siswa kelas VII di SMPN 1 Singosari, 3. mengetahui seberapa tinggi tingkat pengaruh pola asuh orang tua dan penggunaan gadget terhadap hasil belajar mata pelajaran IPS siswa kelas VII di SMPN 1 Singosari. Metode yang digunakan adalah penelitian kuantitatif dengan pendekatan korelasional. Populasi dalam penelitian ini adalah siswa kelas VII SMP Negeri 1 Singosari jumlahnya 324 siswa dengan mengambil sampel 180 dari populasi siswa. Analisis data yang digunakan dalam penelitian ini menggunakan uji asumsi klasik berupa uji normalitas, uji multikolinieritas, uji heteroskesdastisitas, autokorelasi dananalisis regresi linier berganda, determinasi, uji t dan uji F.Hasil penelitian menunjukkan bahwa variabel pola asuh orang tua dan penggunaan gadget secara bersama-sama atau secara simultan berpengaruh terhadap hasil belajar mata pelajar IPS siswa kelas VII SMPN 1 Singosari, artinya semakin optimal pola asuh orang tua, semakin optimal penggunaan gadgetyang digunakan dengan benar dan pengawasan orang tua dalam penggunaan gadget maka akan mempengaruhi hasil belajar siswa dan hasil belajar siswa akan semakin baik.
\end{abstract}

\section{Kata Kunci: pola asuh orang tua; penggunaan gadget; hasil belajar}

Abstrack: Based on the theory of learning outcomes, Clark states that student learning outcomes in schools are $70 \%$ influenced by students' abilities and $30 \%$ are influenced by the environment. The part of the environment is parents and technology (gadgets). To prove the theory, the purpose of this research is 1. Find out the influence level of parental care on social science learning achievement of Grade VII students in SMPN 1 Singosari, 2. find out the influence level of gadget use on social science learning achievement of Grade VII students in SMPN 1 Singosari, 3. find out the influence level of parental care and gadget use on social science learning achievement of Grade VII students in SMPN 1 Singosari. To achieve the aims, the researcher employed quantitative research using correlational approach. The population consists of 324 students of Grade VII in SMP Negeri 1 Singosariand the researcher took 180 samples out of the population. The data analysis is conducted using classical assumption tests such as normality test, multicollinearity test, heteroscedasticity test and multiple linear 
regression analysis, determination, $t$-test and $F$-test. The results showed that parenting and the use of gadgets simultaneously or simultaneously affect the results of students' eyes IPS student grade VII SMPN 1 Singosari, meaning that the more optimal parent care pattern, bush in the optimal use of the gadgets used properly and parental supervision in the use of gadgets will affect student learning outcomes and student learning outcomes will be better.

\section{Keywords: Parental Care; Gadget Use, Learning Outcomes}

\section{PENDAHULUAN}

Belajar merupakan suatu kegiatan yang dilakukan dengan melibatkan dua unsur yakni jiwa dan raga sehingga dapat disimpulkan bahwa belajar adalah serangkaian kegiatan jiwa raga untuk memperoleh suatu perubahan baik segi tingkah laku sebagai hasil dari pengalaman individu dalam interaksi dengan lingkungan yang menyangkut aspek kognitif, afektif dan psikomotik. Hasil belajar adalah pola perbuatan, nilai-nilai, pengertian-pengertian, sikap-sikap, apresiasi, dan keterampilan.

Berdasarkan teori hasil belajar, Clark menyatakan hasil belajar siswa di sekolah $70 \%$ dipengaruhi oleh kemampuan siswa dan 30\% dipengaruhi oleh lingkungan. Adapun bagian dari lingkungan itu adalah orang tua dan teknologi (gadget). Orang tua memiliki pengaruh yang sangat besar terhadap keberhasilan belajar siswa. Apabila keluarga khusunya orang tua bersifat mendorong dan membimbing terhadap aktivitas belajar anak, maka kemungkinannya anak tersebut akan dapat meraih prestasi yang tinggi. Sebaliknya apabila orang tua acuh dan tidak peduli sama sekali dengan aktivitas belajar anak baik di dalam maupun di luar rumah maka akan sulit bagi sang anak untuk memperoleh prestasi yang baik. Suasana rumah, hubungan antara keluarga yang harmonis, cara orang tua mendidik dan keadaan ekonomi keluarga juga dapat memberi dampak baik atau buruk terhadap kegiatan belajar dan hasil yang dicapai oleh siswa (Syah, 1999).

Gadget adalah sebuah piranti atau instrumen elektronik yang memiliki tujuan dan fungsi praktis yang secara khusus yakni dirancang lebih canggih dibanding dengan teknologi yang telah diciptakan sebelumnya. Perbedaan gadget dengan instrumen teknologi yang lainnya yakni dari unsur kebaruannya yang berukuran kecil, Sedangkan menurut Derry Iswhidarmanjaya gadget adalah perangkat atau instrumen elektronik yang memiliki tujuan dan fungsi yang praktis terutama untuk membantu pekerjaan manusia (Iswhidarmanjaya),

Gadget mimiliki pengaruh positif dan pengaruh negative terhadap proses pembelajaran maupun hasil belajar. Pengaruh positif nya yaitu gadget, dapat membantu mereka untuk merangsang indera dan imajinasi mereka. Selain itu, gadget juga dapat membantu kemampuan mendengarkan, belajar suara dan juga kemampuan berbicara,berbagai perangkat gadget dan aneka aplikasi permainan, mendorong kognitif dan pengembangan keterampilan analistis. Juga membantu dalam mengembangkan pemikiran inovatif, pemikiran strategis, investigasi keterampilan dan meningkatkan potensi kreativitas anak-anak. Jika dilihat dari dampak positifnya, maka gadget akan meningkatkan hasil belajar siswa.

Adapun dampak negative gadget jika berlebihan adalah kecenderungan anak menjadi kurang kreatif lagi. Itu dikarenakan ketika ia diberi tugas oleh sekolah ia tinggal browsing internet untuk menyelesaikan tugas. Selain itu, Priyatna (2012) mengungkapkan beberapa dampak negatif lainnya yaitu dijelaskan berikut ini: 
1. Anak yang terbiasa bermain game lebih dari 1 jam perhari atau rata-rata 7-10 jam per minggu, boleh jadi mereka akan mengorbankan jatah waktu untuk mengerjakan PR dan waktu untuk belajar yang berakibat negatif untuk prestasi akademiknya di sekolah.

2. Anak menjadi malas untuk melakukan aktivitas fisik yang berimbas pada kesehatan anak. Jika anak terus menerus manatap layar pada gawai, hal itu dapat menyebabkan masalah pada penglihatan. Terlalu banyak duduk ketika bermain gawai juga dapat menyebabkan masalah pada tulang, sendi dan otot. Bahkan kurangnya aktivitas fisik juga dapat meningkatkan resiko mengalami kelebihan berat badan atau obesitas.

SMP Negeri 1 Singosari merupakan salah satu dari sekian instansi atau lembaga pendidikan yang ikut serta dan aktif dalam mengembangkan dan meningkatkan mutu pendidikan dan mewujudkan sumber daya manusia yang mempunyai kompetensi, pengetahuan dan wawasan yang luas. Berdasarkan data BK (bimbingan konseling) siswa yang berada di di SMP Negeri 1 Singosari mempunyai latar belakang keluarga yang berbeda-beda, ada yang latar belakang pekerjaan orang tuanya yakni TNI, guru, wiraswasta, dan buruh. Dari latar belakang keluarga yang berbeda maka pastilah pola pengasuhan atau cara mendidik yang diberikan oleh orang tua mereka pasti berbeda dan bervariasi.

SMP Negeri 1 Singosari juga tidak mau ketinggalan dalam hal memanfaatkan perkembangan teknologi yang ada sekarang. Para guru dan siswa yang ada di SMP Negeri 1 Singosari memanfaatkan gadget yang berupa komputer, laptop, lcd, dan sebagai alat dalam menunjang pembelajaran dalam kelas. Berdasarkan uraian di atas maka penelitian ini berupaya untuk menjelaskan dan mengkaji sejauh mana pengaruh pola asuh orang tua dan penggunaan gadget terhadap hasil belajar mata pelajaran IPS siswa kelas VII SMP Negeri 1 Singosari.

\section{METODE}

Peneliti menggunakan penelitian dengan jenis kuantitatif. Dalam penelitian ini terdapat 2 kelompok variabel yaitu 1. variabel bebas yaitu Pola asuh orang tua $\left(\mathrm{X}_{1}\right)$, dan penggunaan gadget $\left(\mathrm{X}_{2}\right)$ pada mata pelajaran IPS kelas VII di SMP Negeri 1 Singosari. 2. Variabel terikat (Dependent Variable) atau variabel $\mathrm{Y}$ yaitu hasil belajar mata pelajaran IPS kelas VII di SMP Negeri 1 Singosari. Peneliti dalam menerapkan angket atau kuesioner menggunakan skala Likert. Adapun kisi-kisi instrumen dalam penelitian ini sebagai berikut:

Tabel. I. Kisi-kisi Instrumen Pola Asuh Orang Tua

\begin{tabular}{|c|c|c|c|}
\hline Variabel & Sub variabel & Indikator & Item \\
\hline \multirow{8}{*}{$\begin{array}{l}\text { Pola Asuh } \\
\text { Orang } \\
\text { Tua }\end{array}$} & \multirow{3}{*}{$\begin{array}{l}\text { Authoritarian } \\
\text { Parenting } \\
\text { (Otoriter) }\end{array}$} & Menerapkan kontrol diri secara kaku & 1,2 \\
\hline & & $\begin{array}{l}\text { Selalu mengkritik tentang perilaku anak dan } \\
\text { menghkum sesuka hati }\end{array}$ & 3,4 \\
\hline & & Membolehkan sedikit diskusi & 5 \\
\hline & \multirow{5}{*}{$\begin{array}{l}\text { Authoritative } \\
\text { Parenting } \\
\text { (demokratis) }\end{array}$} & Mendukung anak menjadi mandiri tetapi tetap & 6 \\
\hline & & $\begin{array}{l}\text { menempatkan batasan dan kontrol pada tindakan } \\
\text { mereka. }\end{array}$ & \\
\hline & & Memberikan kesempatan berdialog secara verbal & 7 \\
\hline & & Dekat secara emosional dan tindakan yang hangat & 8,9 \\
\hline & & $\begin{array}{l}\text { Menunjukkan rasa kepedulian dengan } \\
\text { menunjukkan rasa senang atas perilaku anak yang } \\
\text { membangun }\end{array}$ & 10 \\
\hline
\end{tabular}




\begin{tabular}{|c|c|c|c|}
\hline & $\begin{array}{l}\text { Neglectful } \\
\text { Parenting } \\
\text { (melalaikan) }\end{array}$ & $\begin{array}{l}\text { Orang tua sangat tidak terlibat dalam aktivitas } \\
\text { anak } \\
\text { Tidak ada tuntutan dan kontrol }\end{array}$ & $13,14,1$ \\
\hline (referensi: & & $\begin{array}{l}\text { Tidak begitu tertatrik pada pendapat dan kegiatan } \\
\text { anak baik di luar ataupun di dalam sekolah. }\end{array}$ & $\begin{array}{l}16,17,1 \\
8,19,20\end{array}$ \\
\hline $\begin{array}{c}\text { John } \\
\text { Santrock. }\end{array}$ & $\begin{array}{l}\text { Indulgent } \\
\text { parenting }\end{array}$ & $\begin{array}{l}\text { Sangat terlibat dengan anak namun menempatkan } \\
\text { sedikit tuntutan atau kendali pada mereka. }\end{array}$ & $\begin{array}{l}21,22,2 \\
3\end{array}$ \\
\hline 2007. & (memanjakan) & Membiarkan anak melakukan apa yang diinginkan & $24,25,2$ \\
\hline $\begin{array}{l}\text { Remaja } \\
\text { edisi }\end{array}$ & & anak & $6,27,28$ \\
\hline kesebelas. & & & \\
\hline $\begin{array}{c}\text { Jakarta: } A i \\
\text { rlangga) }\end{array}$ & & & \\
\hline
\end{tabular}

Tabel II. Kisi-kisi Instrumen Penggunaan Gadget

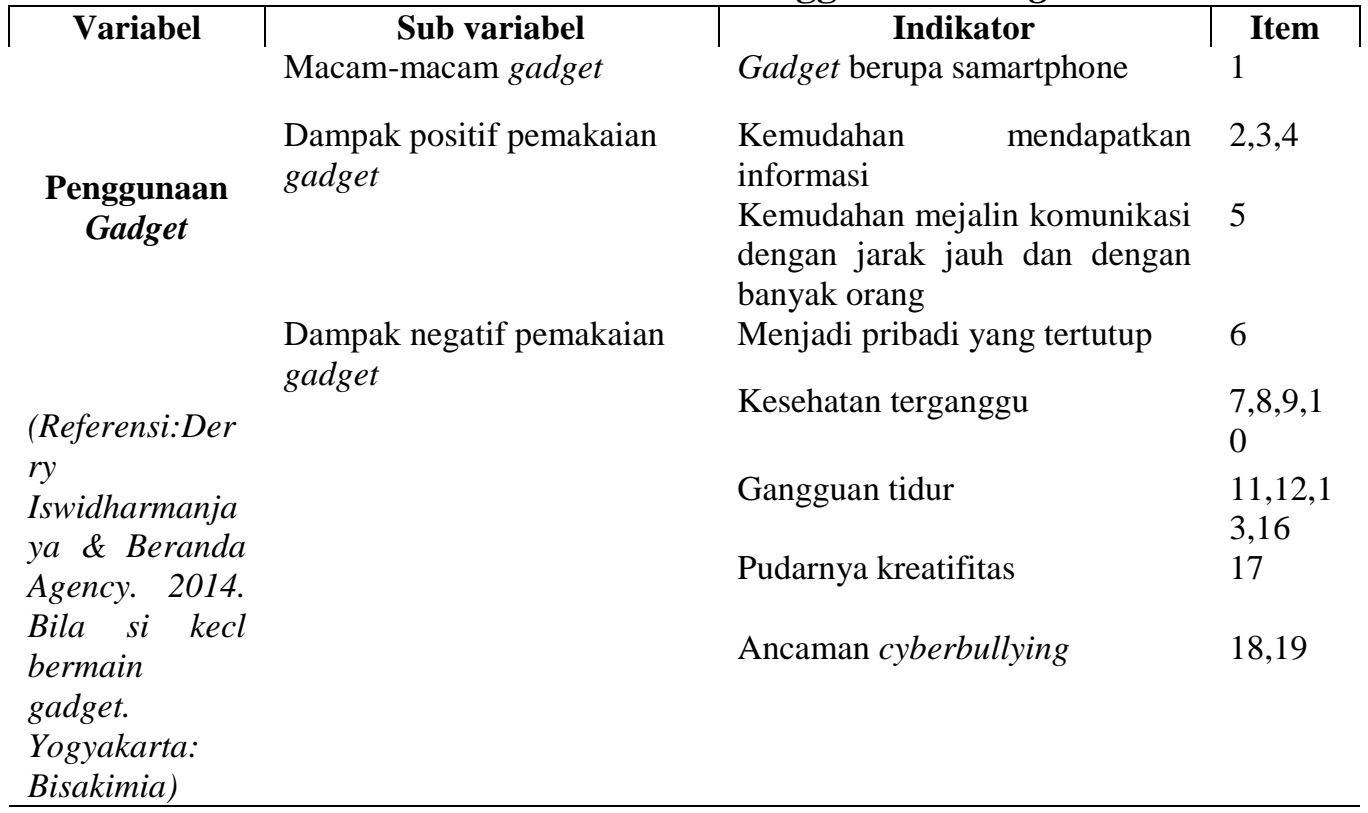

Analisis yang digunakan untuk mengetahui pola asuh orang tua dan intensitas pemakaian gadget terhadap hasil belajar mata pelajaran ekonomi yaitu regresi linier berganda.

\section{HASIL dan PEMBAHASAN \\ Hasil}

Berdasarkan hasil angket yang disebarkan peneliti kepada siswa sebanyak 180 responden dapat diketahui bahwa pola asuh dengan kriteria rendah sebesar $44 \%$ dari 80 siswa, kriteria sedang sebesar 53\% dari 95 siswa, kriteria tinggi 3\% dari 5 siswa. Hasil angket yang disebarkan peneliti kepada siswa sebanyak 180 responden dapat diketahui bahwa penggunaan gadget dengan kriteria rendah sebesar 35\% dengan frekuensi 64 responden, kriteria sedang sebesar 62\% dengan frekuensi 111 responden dan pada kategori tertinggi ada 3\% dengan frekuensi 5 responden. Setelah dilakukannya uji F di dapatkan hasil pada penelitian ini yaitu $F_{\text {hitung }}(3,366)>t_{\text {tabel }}(3,05)$ dan nilai signifikasi $(0,037)<(0,05)$ yang artinya Ho ditolak, maka dapat dinyatakan bahwa variabel pola asuh orang tua dan penggunaan gadget secara bersama-sama atau secara simultan berpengaruh terhadap hasil belajar mata pelajar IPS siswa kelas VII SMP Negeri 1 
Singosari, artinya semakin optimal pola asuh orang tua dan semakin optimal penggunaan gadget yang digunakan dengan benar maka akan mempengaruhi hasil belajar siswa dan hasil belajar siswa akan semakin baik.

\section{Pembahasan \\ Pengaruh Pola Asuh Orang Tua Terhadap Hasil Belajar Mata Pelajaran IPS Siswa Kelas VII SMPN 1 Singosari}

Hasil dalam penelitian ini menunjukkan kecenderungan pola asuh orang tua pada subjek penelitian berada pada kategori sedang. Hal ini disebabkan oleh beberapa faktor, seperti kesibukan orang tua yang bekerja, tingkat pendidikan atau pengetahuan tentang pola pengasuhan terhadap anak, latar belakang status sosial ekonomi dan keadaan yang ada di dalam keluarga.

Pola asuh yang berada di SMP Negeri 1 Singosari dengan latar keluarga yang berbeda-beda pula maka pola pengasuhan yang diterapkan oleh orang tua siswa yang ada di SMP Negeri 1 Singosari.Ada orang tua yang memang dalam mengasuh atau mendidik anaknya mereka cenderung dengan sikap tegas atau otoriter jadi anak harus mengikuti atau menuruti permintaan orang tua namun peneliti melihat bahwa rata-rata orang tua yang berada di SMP Negeri 1 Singosari menerapkan pola pengasuhan sesuai dengan situasi dan kondisi anak.

Selain itu, hasil analisis data yang dilakukan secara parsial menyatakan bahwa pola asuh orang tua berpengaruh positif dan signifikan terhadap hasil belajar mata pelajaran IPS siswa Kelas VII SMP Negeri 1 Singosari. Hal ini sesuai dengan pernyataan dari Muhibbin Syah orang tua memiliki pengaruh yang sangat besar terhadap keberhasilan belajar siswa. Apabila keluarga khusunya orang tua bersifat mendorong dan membimbing terhadap aktivitas belajar anak, maka kemungkinannya anak tersebut akan dapat meraih hasil yang baik dan prestasi yang tinggi. Sebaliknya apabila orang tua acuh dan tidak peduli sama sekali dengan aktivitas belajar anak baik di dalam maupun di luar rumah maka akan sulit bagi sang anak untuk memperoleh prestasi yang baik. Suasana rumah, hubungan antara keluarga yang harmonis, cara orang tua mendidik dan keadaan ekonomi keluarga juga dapat memberi dampak baik atau buruk terhadap kegiatan belajar dan hasil yang dicapai oleh siswa (Syah, 1999).

Dengan adanya perhatian yang lebih intens dari orang tua kepada sang anak maka memberikan beberapa pengaruh dan manfaat bagi perkembangan anak yaitu:

a. Anak dapat lebih terbuka kepada orang tua mengenai segala sesuatu yang terjadi kepada mereka.

b. Anak tidak merasa bahwa kepentingan orang tua atau pekerjaan orang tua lebih berharga ketimbang mereka.

c. Anak akan lebih semangat dalam melakukan segala sesuatu baik itu di dalam rumah ataupun di luar rumah, jika perhatian orang tua kepada mereka baik.

d. Anak akan terus memperbaiki diri jika orang tua selalu membimbing dan tidak lupa mengarahkan tingkah laku anak.

Adapun Orang tua yang memberikan kasih sayang, perhatian, ataupun cara mendidik dan mengasuh anak yang baik maka dapat tercermin dari diri seorang anak apakah ia berhasil atau tidak dalam hidupnya, yang contoh kecilnya adalah berhasil dalam pendidikan seperti hasil belajar yang didapatkan mendapatkan nilai yang baik dan memuaskan. Hal ini sesuai dalam buku karya M. Musyrofi yang mana dari berbagai cerita sejarah bahwa tokoh-tokoh hebat ternyata hasil didikan dari ibu mereka. Seperti Imam Syafi'i yang hafal Al-Qur'an pada umur tujuh tahun karena didikan dari seorang 
ibu. Kemudian George Washington, seorang presiden Amerika Serikat, menuliskan bahwa beliau dididik oleh ibunya sehingga menjadi seorang yang berhasil. Dan juga, Albert Einstein juga pendidikannya diambil alih oleh ibunya ketika beliau dikatakan bodoh oleh gurunya sendiri, dan masih banyak lagi tokoh-tokoh hebat yang dididik oleh seorang ibu yang hebat (Musyrofi, 2010). Dan pola asuh orang tua termasuk salah satu dari faktor eksternal dalam hasil belajar, yakni cara orang tua mendidik anak, relasi anggota keluarga, suasana rumah tangga dan keadaan ekonomi.

Sejalan dengan pendapat M. Musyrofi (2010) dalam karyanya yang bercerita tentang berbagai cerita sejarah tokoh-tokoh hebat ternyata didikan dari ibu mereka, dalam buku yang ditulis oleh Juwariyah yang berjudul dasar-dasar pendidikan anak dalam Al-Qur'an beliau menceritakan juga tentang tokoh besar yakni Thomas Alfa Edison adalah seorang yang memiliki masa kecil yang tragis, oleh gurunya ia dianggap bodoh, bahkan dikatakan tidak mampu mengikuti pelajaran di sekolah, sehingga diapun dikeluarkan dari sekolah. akan tetapi ibunya Marry Edison mampu membangkitkan semangat dan motivasi Edison kecil dengan motivasi dan keyakinan yang luar biasa. Sang ibu menunjukkan kepada dunia bahwa anaknya adalah anak yang cerdas. Dengan penuh kasih sayang, bimbingan dan pelajaran yang diberikan sang ibu Edison menjadi manusia yang benar-benar jenius, yang mampu melampaui kecerdasan anak-anak yang sebaya dengannya. Pada masa jayanya Edison pernah mengatakan bahwa orang yang paling berperan dalam menentukan kejayaannya adalah ibu (Juwariyah, 2010).

Dari berbagai cerita di atas tentang tokoh-tokoh yang berhasil dalam kehidupannya, tidak dapat dipungkiri bahwa peran orang tua terutama seorang ibu adalah menjadi faktor utama dan faktor penting dalam menentukan kehidupan dan keberhasilan anaknya kelak. Maka dengan itu sebagai orang tua dan sekaligus pendidik yang bijak haruslah paham tentang karakteristik anak, konsep pendidikan anak, dan juga harus mempunyai kreatifitas. Karena dari ketiga substansi tersebut sangatlah berpengaruh terhadap proses pendidikan anak, apakah proses pendidikan anak akan berhasil atau tidaknya bergantung kepada pola pengasuhan dan cara mendidik anak sedari kecil.

Hal ini juga diperkuat dengan hasil penelitian yang dilakukan oleh Chairatul Umami Rusdiah, yang berjudul tentang pengaruh pola asuh dan status sosial ekonomi orangtua terhadap hasil belajar mata pelajaran geografi siswa kelas X IPS di MAN 1 Malang. hasil penelitian menunjukkan besaran pengaruh variabel pola asuh berpengaruh signifikan terhadap hasil belajar sebesar 0,073. Maka dapat disimpulkan bahwa memang pola asuh orang tua berpengaruh terhadap hasil belajar siswa, dan pengaruhnya yang diperoleh adalah sebesar 0,073. Penelitian ini juga sejalan dengan penelitian yang dilakukan oleh Khilyatul A'immah dengan judul penelitian yakni pengaruh pola asuh orang tua dan motivasi belajar terhadap hasil belajar mata pelajaran IPS siswa kelas VIII SMP Negeri 6 Malang. hasil penelitian menunjukkan bahwa ada pengaruh positif signifikan antara pola asuh orang tua terhadap hasil belajar mata pelajaran IPS siswa kelas VIII SMP Negeri 6 Malang sebesar 0,112 atau 11,2\%.

\section{Pengaruh Penggunaa Gadget Terhadap Hasil Belajar Mata Pelajaran IPS Siswa Kelas VII SMPN 1 Singosari}

Hasil analisis data yang dilakukan secara parsial menyatakan bahwa penggunaan gadget tidak berpengaruh positif signifikan terhadap hasil belajar mata pelajaran IPS siwa kelas VII SMP Negeri 1 Singosari. Hal ini berarti penggunaan gadget berupa smartphone atau handphone tidak dapat menyebabkan meningkatnya hasil belajar mata 
pelajaran IPS siswa kelas VII SMP Negeri 1 Singosari. Hal ini berlawanan dengan hasil penelitian yang telah dilakukan oleh Syamsul Arifin yang menunjukkan bahwa gadget berpengaruh positif siginifikan terhadap hasil belajar siswa (Arifin:2015). akan tetapi temuan pada penelitian ini sejalan dengan penelitian yang telah dilakukan oleh Maya Ferdiana Rozalia yang menunjukkan bahwa tidak ada pengaruh positif signifikan antara intensitas penggunaan gadget terhadap hasil belajar (Rozalia:2009).

Temuan dalam penelitian ini mengindikasikan bahwa faktor-faktor lain di luar penggunaan gadget berupa smartphone yang mempengaruhi hasil belajar siswa. karena masih banyak faktor yang dapat mempengaruhi siswa dalam meningkatkan hasil belajarnya dalam hal ini pemakaian gadget yang berupa komputer, laptop, sarana dan prasaran yang ada di sekolah, faktor jasmani, faktor psikologis, faktor media massa, faktor teman sebaya, faktor diri sendiri dan lain sebagainya.

Dewasa ini penggunaan gadget oleh anak usia sekolah sudah bukan lagi menjadi sesuatu yang aneh, karena biasanya orang tua memberikan gadget sebagai hadiah atas prestasi yang di raih oleh anaknya atau mungkin orang tua yang memberikan gadget terhadap anaknya hanya untuk memenuhi kebutuhan anak saat ini dengan alat komunikasi berupa gadget. Siswa yang pandai dalam memanfaatkan gadget-nya tentunya akan menggunakan gadget tersebut untuk kepentingan belajarnya.

Ketika penggunaan gadget secara parsial tidak berpengaruh positif signifikan terhadap hasil belajar siswa, salah satu kemungkinan dapat terjadi adalah karena faktor sikap siswa, sarana dan pra-sarana di sekolah, teman sebaya, psikologis, jasmani, media massa, motivasi siswa, kecerdasan siswa, atau pun faktor-faktor lain yang dapat mempengaruhi hasil belajar siswa. Adapun teori yang menunjang penelitian yakni yang dikemukakan oleh derry iswidharmanjaya yang mengatakan di dalam bukunya bahwa selain dampak positif, gadget juga mempunyai dampak negatifnya yakni yang berupa: (a) Menjadi pribadi yang tertutup; ketika anak telah kecanduan yang namanya gadget maka mereka pasti akan menganggap bahwa gadget itu adalah segalanya bagi mereka, dan biasanya anak yang sudah kecanduan gadget mereka akan merasa cemas kalau gadget mereka ketinggalan. Bahkan mereka akan lebih senang bermain gadget daripada berkumpul dengan keluarga dan teman sebayanya; (b) kesehatan otak terganggu; (c) kesehatan mata terganggu; (d) kesehatan tangan terganggu; (e) gangguan tidur; (f) suka menyendiri; (g) perilaku kekerasan; (g) suka menyendiri; (h) pudarnya kreatifitas; (i) terpapar radiasi; dan yang terakhir yakni (j) ancaman cyberbullying.

Dari penjelasan tentang dampak negatif dari penggunaan gadget yang salah maka akan menurunkan hasil belajar siswa. Karena dari gadget yang mereka miliki tidak dipergunakan dengan baik dan tidak dioptimalkan untuk mencari informasiinformasi tentang pelajaran ataupun untuk memperluas wawasan di bidang keilmuan yang mereka tekuni di sekolah, kebanyakan dari siswa yang memiliki gadget berupa smartphone mereka menggunakan gadget untuk bermain game baik game online ataupun game offline, chatingan dnegan teman, update media sosial seperti instagram, whatsapp, facebook dan lain sebagainya.

Kaitan dengan penelitian ini, walaupun pengaruh penggunaan gadget tidak berpengaruh positif signifikan terhadap hasil belajar siswa, orang tua beserta guru yang ada di sekolah harus tetap melakukan pengawasan kepada siswa agar tidak menyalahgunakan penggunaan gadget untuk hal-hal yang menyimpang yang mengarah kepada perilaku yang kurang terpuji, sehingga menyebabkan siswa kurang fokus dalam pembelajaran. Orang tua dan guru hendaknya selalu mengarahkan kepada hal-hal yang positif dan bermanfaat bagi anak dikehidupan selanjutnya. 


\section{Pengaruh Pola Asuh Orang Tua dan Penggunaan Gadget Hasil Belajar Mata Pelajaran IPS Siswa Kelas VII SMPN 1 Singosari}

Slameto berpendapat bahwa faktor-faktor yang mempengaruhi hasil belajar meliputi faktor internal dan faktor eksternal. Faktor keluarga dan penggunaan gadget merupakan salah satu eksternal yang dapat mempengaruhi hasil belajar siswa (Slameto, 2003). Di antara banyak faktor yang mempengaruhi hasil belajar tersebut dalam penelitian ini juga diketahui bahwa secara simulan, pola asuh orang tua dan penggunaan gadget juga dapat mempengaruhi hasil belajar siswa. jika seorang siswa yang menggunakan gadget didampingi atau dalam penggunaan gadget pengawasan orang tua sangatlah baik, maka mendapatkan hasil belajar yang baik, karena jika dia menggunakan atau memanfaatkan gadget tanpa pengawasan dari orang tua maka anak dapat menggunakan gadget tersebut dengan memcari hal-hal semau mereka atau mungkin gadget tersebut digunakan untuk bermain game dan tidak untuk belajar. Jika mereka menggunakan gadget dibarengi dengan pengawasan dari orang tua maka orang tua dapat memberi arahan dan bimbingan dalam penggunaan gadget yang baik yang dapat menunjang pembelajaran siswa.

Pola asuh orang tua dan penggunaan gadget di SMP Negeri 1 Singosari secara bersamaan dapat menjadikan hasil belajar siswa semakin baik. Jika pola asuh orang tua dan penggunaan gadget sama-sama dioptimalkan dengan baik maka tidaklah mustahil bahwa kedua hal tersebut dapat berpengaruh kepada anak dan membuat dia bersemangat dalam belajarnya dan nantinya mendapatkan hasil belajar yang baik pula.

\section{KESIMPULAN}

Berdasarkan latar belakang yang sudah dijelaskan dan hasil penelitian yang telah penulis dapatkan, penulis dapat mengambil kesimpulan sebagai berikut:

1. Ada pengaruh signifikan antara pola asuh orang tua terhadap hasil belajar mata pelajaran IPS siswa kelas VII SMP Negeri 1 Singosari. Pola asuh orang tua mempunyai pengaruh yang signifikan terhadap hasil belajar mata pelajar IPS siswa kelas VII SMP Negeri 1 Singosari.

2. Ada pengaruh signifikan antara penggunaan gadget terhadap hasil belajar mata pelajaran IPS siswa kelas VII SMP Negeri 1 Singosari. Penggunaan gadget tidak mempunyai pengaruh positif signifikan terhadap hasil belajar mata pelajaran IPS siswa kelas VII SMPNegeri 1 Singosari.

3. Ada pengaruh positif antara pola asuh orang tua dan penggunaan gadget terhadap hasil belajar mata pelajaran IPS siswa kelas VII SMP Negeri 1 Singosari. Variabel pola asuh orang tua dan penggunaan gadget secara bersama-sama atau secara simultan berpengaruh terhadap hasil belajar mata pelajar IPS siswa kelas VII SMP Negeri 1 Singosari, artinya semakin optimal pola asuh orang tua dan semakin optimal penggunaan gadget yang digunakan dengan benar maka akan mempengaruhi hasil belajar siswa dan hasil belajar siswa akan meningkat secara optimal.

\section{DAFTAR PUSTAKA}

A'immah, Khilyatul. (2017). Pengaruh Pola Asuh Orang Tua dan Motivasi Belajar Terhadap Hasil Belajar Mata Pelajaran IPS Siswa Kelas VIII SMP Negeri 6 Malang. Skripsi, Universitas Islam Negeri Maulana Malik Ibrahim Malang, Indonesia.

Iswhidarmanjaya, Derry. (2014). Bila Si Kecil Bermain Gadget. Yogyakarta: Bisakimia. 
Juwariyah. (2010). Dasar-Dasar Pendidikan Anak Dalam Al-Qur'an. Yogyakarta: Teras.

Musyrofi, M. (2010). Melesatkan Prestasi Akademik Siswa. Yogyakarta: Pustaka Insan Madani.

Priyatna, A. (2012). Parenting di Dunia Digital, Jakarta: PT. Indeks.

Rozalia, Maya Ferdiana. (2015) Hubungan Intensitas Pemanfaatan Gadget Terhadap Hasil Belajar Siswa Kelas V SDn Se-Gugus VIII Kecamatan Blimbing Kota Malang. Skripsi, Universitas Negeri Malang, Indonesia.

Rusdiah, Chairatul Umami. (2015). Pengaruh Pola Asuh dan Status Sosial Ekonomi Orangtua Terhadap Hasil Belajar Mata Pelajaran Geografi siswa kelas X IPS di MAN 1 Malang. Skripsi, Universitas Islam Negeri Maulana Malik Ibrahim Malang, Indonesia.

Santrock, John. (2007). Remaja Edisi Kesebelas. Jakarta : Airlangga.

Slameto. (2003). Belajar dan faktor-faktor yang mempengaruhinya. Jakarta: PT Rineka Cipta.

Syah, Muhibbin. (1999). Psikologi Belajar. Yogyakarta: Pustaka Belajar.

Syamsul Arifin. Pengaruh Pemanfaatan Gadget Smartphone dan Fasilitas Belajar Sekolah Terhadap Hasil Belajar Ekonomi Pada Siswa Kelas XI IPS SMA Negeri 6 Malang. (Malang: Skripsi Universitas Negeri Malang, 2015).

Wikipedia. Diambil pada tanggal 18 November, 2017, pukul 22.00 WIB dari https://id.wikipedia.org/wiki/Gawai 